\title{
The impact of financing method on performance of private banking industry
}

\author{
Ali Rouhi ${ }^{\mathrm{a}}$, Afsaneh Tavangar ${ }^{\mathrm{a}}$ and Masoumeh Mohammadi ${ }^{\mathrm{b}}$
}

${ }^{a}$ Assist. Prof. and Faculty member, Department of Accounting, School of Economic and Accounting, Central Tehran Branch, Islamic Azad University (IAU), Tehran, Iran

${ }^{b}$ M.Sc. Student, Department of Accounting, School of Economic and Accounting, Central Tehran Branch, Islamic Azad University (IAU), Tehran, Iran

C H R O N I C L E

\section{Article history:}

Received October 29, 2012

Received in revised format

15 December 2012

Accepted 17 December 2012

Available online

December 182012

Keywords:

Financing

Return of assets

Debt to equity

Performance measurement

\section{A B S T R A C T}

Banking sector has been one of the fastest growing sectors in Iran due to changes in regulations in private banks. In this paper, we perform a survey on the effect of structure of financing on banking performance. The main question of this survey is whether there is any relationship between different methods of financing private banks in terms of their performances. The survey investigates relationship between changes in debt ratio with return of assets, between changes in time dependent investments and return of assets, between changes in long-term investments and return of assets. Finally, we study whether there is a relationship between changes in ratio of total equities to total assets on return of assets. The proposed study of this paper considers three private banks whose shares have been traded on Tehran Stock Exchange namely Eghtesad Novin, Parsian and Saman. The information has been collected over the period 2006-2010. The results of this study indicates that there are some positive and meaningful relationships between changes in time dependent investments, changes in long-term investments ratio of total equities to total assets with return of assets. However, the study did not find any meaningful relationship between changes in total equities to total assets and return of assets.

\section{Introduction}

Return on assets (ROA) is one of the primary ratios for measuring the performance of banking industries and financing methods plays essential role in improving financial performance of banking industries (Modigliani \& Miller, 1958; Myers, 1984). During the past few years, there have been tremendous efforts on using various methods to measure the relative efficiency of banking sectors. Aryanezhad et al. (2011) proposed a method to utilize balanced score card (BSC) as a tool for designing performance evaluation indices of banking sector. The integrated BSC-DEA has been applied as an empirical case for a major private bank organization and the results are analyzed. 
Noori and Taghavi (2012) presented an empirical investigation to learn the effect of some internal and external factors on profitability in banking industry. They introduced three econometrics techniques to investigate the behavior of internal, external and a combination of both factors on ROA. The proposed study of this paper applied Vector Auto- Regressive (VAR) and Vector Error Correction Model (VECM) to incorporate estimation of the model using historical data over the period 1989-2010. They considered some independent variables including ratio of total revenue on total assets (TR) and ratio of total equities on total assets (TE). The second model considered the impacts of external variables on ROA such as growth domestic product (GDP) and market share (MS) and the last model included a combination of both internal and external elements. They reported a positive and meaningful relationship between logarithm of growth domestic product and return on equities.

Khodaei Valahzaghard and Babaei dazghei (2012) performed an empirical study to measure the effect of financial and macro economical figures on capital adequacy. They gathered the necessary data from financial statements and balance sheets of nine Iranian private banks over the period 2005-2011 and reported that there were some meaningful relationship between financial figures, including bank size and profitability, and capital adequacy. However, the survey did not support any relationship between macro economical factors, including growth domestic product and inflations, and capital adequacy. Darvish et al. (2012) performed a survey among 700 employees of private banks in Tehran, Iran and reported that the entrepreneurial orientation, cultural factors and among organizations factors, making proper connections between organizational unit and high manager support had a good condition.

Kashi et al. (2012) performed an investigation on how to introduce high quality services in banking sector using a hybrid of three quality-based methods including SERVQUAL, QFD and Kano models. The results of their survey showed that show that banks' customers were dissatisfied from the quality of services and to solve this problem the bank should do some restructuring to place some special characteristics to reach better operation at the heed of its affairs.

Ghadimi et al. (2012) studied the impacts of various factors on profitability of banking system in Iran for a panel data of period 2001-2010 including ten different banks and two different kinds of internal and external variables were considered. Internal factors included ownership ratio, ratio of bank customers' deposit to banks' assets, ratio of total loans given to all assets, ratio of total interest free loans on total assets, ratio of interest free revenues on total revenue. External factors included economic growth, actual rate of interest and inflation rate. They reported that ownership ratio, ratio of total equity on total assets, along with inflation rate had negative influence on profitability. In addition, the ratio of customers' deposit on total assets, the ratio of total loans on total assets and economic growth had positive effect on profitability.

Khodaei Valahzaghard et al. (2012) measured the effect of various items on risk of foreign currency using value at risk (VaR) and regression techniques. They investigated whether the risk of open positions of six foreign currencies including US dollar, Euro, British Pound, Switzerland Frank, Norwegian Kroner and United Emirate Dirham was increase during the studied time horizon or not. They used historical daily prices of these currencies for a fiscal year of 2011 for one of private banks located in Iran and measured the relative risk. The results of the implementation of two techniques of $\mathrm{VaR}$ and linear regression indicated that the risk of open positions was increased during the time horizon. Gazor et al. (2012) investigated influential factors on knowledge sharing in some Iranian banking industry. Rahaman (2011) studied on why some firms grow faster than others do, explained that many economists strongly disagree on the role of financial structure in influencing firm growth, and suggested that a real effect of financial structure on growth via the channel of an external financing constraint could exist. 
In this paper, we investigate the effect of different financing on performance of some Iranian banks. The organization of this survey first presents details of the findings in section 2 while section 3 presents the results and concluding remarks are given in the last to summarize the contribution of the paper.

\section{The proposed model}

The main question of this survey is find out whether there is any relationship between different methods of financing private banks in terms of their performances. In case the answer is positive, how this relationship is established? In order to answer this question, we need to consider the following sub hypotheses are considered,

1. There is a relationship between changes in debt ratio $\left(\mathrm{X}_{1}\right)$ and return of assets $(\mathrm{Y})$.

2. There is a relationship between changes in time dependent investments $\left(\mathrm{X}_{2}\right)$ and return of assets.

3. There is a relationship between changes in long-term investments $\left(\mathrm{X}_{3}\right)$ and return of assets.

4. There is a relationship between changes in ratio of total equities to total assets $(Z)$ and return of assets.

The proposed study of this paper considers three private banks whose shares have been traded on Tehran Stock Exchange namely Eghtesad Novin, Parsian and Saman. The information has been collected over the period of 2006-2010. In this study, return of assets (Y) is a dependent variable and $X_{1}, X_{2}$ and $X_{3}$ are dependent variables.

\section{The results}

In this section, we present details of our findings on testing four hypotheses of this paper. Table 1 demonstrates some basic observations in terms of mean, median, standard deviation, skewness, Kurtosis, min and max.

\section{Table 1}

Basic statistics

\begin{tabular}{lllllllll}
\hline Variable & Number & Mean & Median & Std. Dev. & Skewness & Kurtosis & Min & Max \\
\hline $\mathrm{X}_{1}$ & 12 & -0.00264 & -0.002 & 0.008616 & 1.19 & 2.386 & -0.013 & 0.018 \\
$\mathrm{X}_{2}$ & 12 & -0.01166 & 0.003 & 0.069763 & -0.850 & 0.547 & -0.161 & 0.086 \\
$\mathrm{X}_{3}$ & 12 & 0.00553 & -0.003 & 0.085918 & 0.0338 & 0.750 & -0.116 & 0.149 \\
$\mathrm{Z}$ & 12 & 0.00019 & 0.000 & 0.008980 & -0.629 & 2.868 & -0.021 & 0.015 \\
$\mathrm{Y}$ & 12 & 0.00065 & 0.002 & 0.003340 & -0.421 & -0.175 & -0.006 & 0.005 \\
\hline
\end{tabular}

In order to investigate whether the data are normally distributed or not we use Kolmogorev-smirnov test (Peacock, 1983) where the null hypothesis is that data are normally distributed and Table 2 summarizes the results.

\section{Table 2}

The summary of Kolmogorev-smirnov test (KS) for changes on return on assets

\begin{tabular}{llllllll}
\hline \multicolumn{7}{l}{ Normal parameters } & \multicolumn{2}{l}{ The maximum difference } & & \\
\hline Number & Mean & Standard deviation & Absolute & positive & negative & KS & P-Value \\
\hline 12 & 0.00065 & 0.00341 & 0.188 & 0.122 & -0.188 & 0.653 & 0.788 \\
\hline
\end{tabular}

As we can observe from the results of Table 2, P-value is well more than 0.05 and we cannot reject the null hypothesis and the distribution is normal. Next, we study the relationship between some dependent variables using Spearman correlation ratios. Note that when there is a linear relationship 
between independent variables, there may be some confusing results. Therefore, we need to make sure there is no strong collinearity among dependent variables.

\subsection{Testing the first hypothesis}

The first hypothesis of this paper investigates whether there is a meaningful relationship between changes in debt ratio and changes return of assets (ROA).

$$
\left\{\begin{array}{l}
H_{0}: \rho_{X Y}=0 \\
H_{1}: \rho_{X Y} \neq 0
\end{array}\right.
$$

Table 3 shows details of our finding using Pearson correlation ratio.

Table 3

The results of Pearson correlation ratio

\begin{tabular}{llll}
\hline & Statistics & Changes on ROA & Changes on debt ratio \\
\hline \multirow{3}{*}{ Changes on ROA } & Pearson correlation & 1.00 & 0.79 \\
& P-value & - & 0.00 \\
& Number & 12 & 12 \\
\hline \multirow{3}{*}{ Changes on debt ratio } & Pearson correlation & 0.79 & 1.00 \\
& P-value & 0.00 & - \\
& Number & 12 & 12 \\
\hline
\end{tabular}

As we can observe from the results of Table 3, there is a meaningful and positive correlation between changes on ROA and changes on debt ratio. Therefore, we can perform a linear regression analysis using ordinary least square (OLS) technique to study the effect of changes in debt ratio $\left(\mathrm{X}_{1}\right)$ with return of assets $(\mathrm{Y})$, which is associated with the first hypothesis of this survey.

$$
Y_{i t}=\beta_{0}+\beta_{1} X_{1 i t}+\varepsilon_{i t}
$$

Table 4 shows details of analysis of variance (ANOVA).

Table 4

The results of ANOVA test

\begin{tabular}{llllll}
\hline & Sum Square & df & Mean of Square & F & P-value \\
\hline Regression & $6.83 \mathrm{E}-05$ & 1 & $6.83 \mathrm{E}-05$ & & 12.549 \\
Residual & $5.45 \mathrm{E}-05$ & 10 & $5.45 \mathrm{E}-06$ & & 0.005 \\
\hline Total & $1.23 \mathrm{E}-05$ & 11 & & & \\
\hline
\end{tabular}

The resulst of ANOVA yieds F-value is equal to 12.549 with P-value of 0.005 and this value confirms the linear relationship between these two variables. Table 5 shows details of our findings,

\section{Table 5}

The results of regression analysis

\begin{tabular}{llllll}
\hline Parameter & Coefficients & Standard coefficent & Standard beta & t-value & P-value \\
\hline Intercept & $\beta_{0}$ & 0.001 & & 3.160 & 0.010 \\
Debt to equity & $\beta_{1}$ & 0.0817 & 0.74 & 3.542 & 0.005 \\
\hline
\end{tabular}

The solpe of the regression function is calculated as 0.289 with standard deviation of 0.0817 and Durbin-Watson value of 2.16, which means there is no auto correlation between residuals in regression function. Therefore, we can conclude that an increase of one unit in changes in debt ratio will increase ROA by 0.289 . 


\subsection{Testing the second hypothesis}

The second hypothesis of this paper investigates whether there is a meaningful relationship between changes in time dependent investment and changes return of assets (ROA).

$$
\left\{\begin{array}{l}
H_{0}: \rho_{X Y}=0 \\
H_{1}: \rho_{X Y} \neq 0
\end{array}\right.
$$

Table 6 shows details of our finding using Pearson correlation ratio.

Table 6

The results of Pearson correlation ratio

\begin{tabular}{llll}
\hline & Statistics & Changes on ROA & Time dependent investment \\
\hline \multirow{3}{*}{ Changes on ROA } & Pearson correlation & 1.00 & 0.786 \\
& P-value & - & 0.00 \\
& Number & 12 & 12 \\
\hline \multirow{3}{*}{ Time dependent investment } & Pearson correlation & 0.786 & 1.00 \\
& P-value & 0.00 & - \\
& Number & 12 & 12 \\
\hline
\end{tabular}

It can be observed from the results of Table 6 that there is a meaningful and positive correlation between changes on ROA and changes on time dependent investment. Therefore, we can perform a linear regression analysis using ordinary least square (OLS) technique to study the effect of changes in time dependent investment $\left(\mathrm{X}_{2}\right)$ with return of assets $(\mathrm{Y})$, which is associated with the second hypothesis of this survey.

$Y_{i t}=\beta_{0}+\beta_{1} X_{2 i t}+\varepsilon_{i t}$

Table 7 shows details of analysis of variance (ANOVA).

Table 7

The results of ANOVA test

\begin{tabular}{llllll}
\hline & Sum Square & df & Mean of Square & F & P-value \\
\hline Regression & $7.15 \mathrm{E}-05$ & 1 & $7.15 \mathrm{E}-05$ & & 13.921 \\
Residual & $5.13 \mathrm{E}-05$ & 10 & $5.13 \mathrm{E}-06$ & & 0.004 \\
\hline Total & $1.23 \mathrm{E}-05$ & 11 & & & \\
\hline
\end{tabular}

The resulst of ANOVA yieds F-value is equal to 12.549 with P-value of 0.005 and this value confirms the linear relationship between these two variables. Table 8 shows details of our findings,

\section{Table 8}

The results of regression analysis

\begin{tabular}{llllll}
\hline Parameter & Coefficients & Standard deviation & Standard beta & t-value & P-value \\
\hline Intercept & 0.0023 & 0.001 & & 3.31 & 0.008 \\
$\mathrm{X}_{2}$ & 0.0348 & 0.0093 & 0.76 & 3.73 & 0.004 \\
\hline
\end{tabular}

The solpe of the regression function is calculated as 0.035 with standard deviation of 0.0817 and Durbin-Watson value of 1.71 , which means there is no auto correlation between residuals in regression function. Therefore, we can conclude that an increase of one unit in changes in time dependent investment will increase ROA by 0.0348 . 


\subsection{Testing the third hypothesis}

The third hypothesis of this paper investigates whether there is a meaningful relationship between changes in long-term investment and changes return of assets (ROA).

$$
\left\{\begin{array}{l}
H_{0}: \rho_{X Y}=0 \\
H_{1}: \rho_{X Y} \neq 0
\end{array}\right.
$$

Table 9 shows details of our finding using Pearson correlation ratio.

\section{Table 9}

The results of Pearson correlation ratio

\begin{tabular}{llll}
\hline & Statistics & Changes on ROA & Long-term investment \\
\hline \multirow{3}{*}{ Changes on ROA } & Pearson correlation & 1.00 & 0.71 \\
& P-value & - & 0.01 \\
& Number & 12 & 12 \\
\hline \multirow{3}{*}{ Long-term investment } & Pearson correlation & 0.71 & 1.00 \\
& P-value & 0.01 & - \\
\hline & Number & 12 & 12 \\
\hline
\end{tabular}

Again, it is obvious from the results of Table 9 that there is a meaningful and positive correlation between changes on ROA and changes on time dependent investment. Therefore, we can perform a linear regression analysis using ordinary least square (OLS) technique to study the effect of changes in long term investment $\left(\mathrm{X}_{3}\right)$ and return of assets $(\mathrm{Y})$, which is associated with the third hypothesis of this survey.

$$
Y_{i t}=\beta_{0}+\beta_{1} X_{3 i t}+\varepsilon_{i t}
$$

Table 10 shows details of analysis of variance (ANOVA).

Table 10

The results of ANOVA test

\begin{tabular}{llllll}
\hline & Sum Square & df & Mean of Square & F & P-value \\
\hline Regression & $5.98 \mathrm{E}-05$ & 1 & $5.98 \mathrm{E}-05$ & & 0.012 \\
Residual & $6.30 \mathrm{E}-05$ & 10 & $6.30 \mathrm{E}-06$ & 9.477 & \\
\hline Total & $1.23 \mathrm{E}-04$ & 11 & & & \\
\hline
\end{tabular}

The resulst of ANOVA yieds F-value is equal to 9.477 with P-value of 0.012 and this value confirms the linear relationship between these two variables. Table 11 shows details of our findings,

\section{Table 11}

The results of regression analysis

\begin{tabular}{llllll}
\hline Parameter & Coefficients & Standard deviation & Standard beta & t-value & P-value \\
\hline Intercept & 0.0015 & 0.001 & & 2.045 & 0.068 \\
$\mathrm{X}_{3}$ & 0.0247 & 0.0080 & 0.698 & 3.078 & 0.012 \\
\hline
\end{tabular}

The solpe of the regression function is calculated as 0.0247 with standard deviation of 0.0080 and Durbin-Watson value of 1.59 , which means there is no auto correlation between residuals in regression function. Therefore, we can conclude that an increase of one unit in changes in time dependent investment will increase ROA by 0.0247 . 


\subsection{Testing the fourth hypothesis}

The fourth hypothesis of this paper investigates whether there is a meaningful relationship between changes in total equities to total assets with changes on return of assets (ROA).

$$
\left\{\begin{array}{l}
H_{0}: \rho_{X Y}=0 \\
H_{1}: \rho_{X Y} \neq 0
\end{array}\right.
$$

Table 12 shows details of our finding using Pearson correlation ratio.

Table 12

The results of Pearson correlation ratio

\begin{tabular}{llll}
\hline & Statistics & Changes on ROA & Total equities to total assets \\
\hline \multirow{3}{*}{ Changes on ROA } & Pearson correlation & 1.00 & 0.455 \\
& P-value & - & 0.14 \\
& Number & 12 & 12 \\
\hline \multirow{3}{*}{ Total equities to total assets } & Pearson correlation & 0.455 & 1.00 \\
& P-value & 0.14 & - \\
& Number & 12 & 12 \\
\hline
\end{tabular}

As we can observe from the results of Table 12, there is not any meaningful correlation between changes on ROA and changes on total equities to total assets and we cannot conclude any perform a linear regression analysis using ordinary least square (OLS) technique to study the effect of changes in Total equities to total assets $(\mathrm{Z})$ with return of assets $(\mathrm{Y})$.

\section{Conclusion}

In this paper, we have presented an empirical investigation to study the impacts of changes on different factors on return of asset for three major private banks in Iran. The proposed study of this paper has gathered the necessary information from formal financial information released by Tehran Stock Exchange. The study has implemented Pearson correlation ratios as well as linear regression technique to examine all hypotheses of the survey. Based on the results of our investigation, changes on debt ratio, time dependent investments with return of assets and long-term investments had positive relationship with return on assets. However, the study did not find any evidence to conclude there was any relationship between changes in total equities to total assets and return on assets.

\section{References}

Aryanezhad, M.B., Najafi, E., \& Bakhshi Farkoosh, S. (2011). A BSC-DEA approach to measure the relative efficiency of service industry: A case study of banking sector. International Journal of Industrial Engineering Computations, 2(2), 273-282.

Darvish, H., Alvani, S.M., salehi sadagiani, J., \& Abbaszadeh, H. (2012). An empirical study on effective factors on entrepreneurial orientation in Iranian banking industry. Management Science Letters, 2(7), 2591-2600.

Gazor, H., Koohkan, F., Kiarazm, A., \& Nazari Ameleh, K. (2012). Influential factors on knowledge sharing in banking industry. Management Science Letters, 2(6), 2215-2224 .

Ghadimi, M., Taghavi, M., \& Kassaipour, N. (2012). A study on the effect of different factors on profitability of banking system. Management Science Letters, 2(6), 1849-2254.

Kashi, M., Astanbous, M.A., Javidnia, M., \& Rajabi, H. (2012). A hybrid model of QFD, SERVQUAL and KANO to increase bank's capabilities. Management Science Letters, 2(6), 19311938. 
Khodaei Valahzaghard, M., \& Babaei dazghei, M. (2012). An empirical study to measure the impact of financial and macro economical figures on capital adequacy. Management Science Letters, 2(8), 2833-2838.

Khodaei Valahzaghard, M., Ghavidel, M., Heidar, M., \& Mahmoudzadeh, E. (2012). An empirical study on open position risk assessment using VAR and regression analysis: A case study of Iranian banking industry. Management Science Letters, 2(6), 2135-2140.

Modigliani, F., \& Miller, M.H. (1958). The cost of capital, corporation finance, and the theory of investment. American Economic Review, 48, 261 - 297.

Myers, S. C. (1984). The capital structure puzzle. Journal of Finance, 39, 575-592.

Noori, H., \& Taghavi, M. (2012). Investigating internal and external factors influencing profitability of banking industry. Management Science Letters, 2(8), 2723-2730.

Peacock, J.A. (1983). Two-dimensional goodness-of-fit testing in astronomy. Monthly Notices of the Royal Astronomical Society, 202, 615-627.

Rahaman, M.M. (2011). Access to financing and firm growth. Journal of Banking \& Finance, 35(3), 709-723. 